\title{
Inside The Room and Beyond
}

\author{
By Rod Stoneman
}

Fall 2011 Issue of KINEMA

\section{INSIDE THE ROOM AND BEYOND}

A cult film like The Room challenges our unquestioning acceptance of well-made mainstream cinema.

When The Room first screened in Los Angeles in 2003, apparently people were rolling in the aisles within the first ten minutes; Variety's review described it as "so hopelessly amateurish that auds [sic] reportedly walked out" and it was quickly and hyperbolically dismissed as "the worst film ever made". Since then this very strange film has gradually been discovered by cult audiences around the world. Tommy Wiseau is producer, director, writer, and actor - he plays the central role of Johnny - the film emanates from a single source, he allegedly paid $\$ 6$ million to have it made.

Ours is a culture that encourages entrepreneurial enterprise and self-assertion. Like other forms of selfpublishing, The Room did not encounter any version of external interaction with an audience, editorial response or test screenings before being released. It is a short circuit of self-expression. The confidence and self-promotion needed to propose his own film had to be eventually re-calibrated in relation to the unexpected reaction of an actual audience. The vulnerability of any kind of an artist has to be protected by a carapace of self-belief and inevitably the larger-than-life chutzpah needed to realise The Room became self-protection when it was reviled. With neat footwork Tommy Wiseau explained that it had been intended as "a quirky new black comedy" from the beginning. But it is clear that the realisation of the risible details its incredulous fans find so hilarious could only have been manufactured unselfconsciously.

The pleasure in the phenomena of cult films often involves discovering the ignored and celebrating the obscure. A highly devoted but relatively small group of fans celebrate a perverse counter taste - 'so bad that it's good'.(1) There is participation, ritual and enactment for The Rocky Horror Picture Show, sing-a-longs with the reissued The Sound of Music and the organised groups drinking in synchrony during screenings of Withnail and $I$ or throwing plastic spoons at the screen at relevant points in The Room. Cult taste evades quality judgements, whether we are talking of a well-regarded classic like The Quiet Man by John Ford or the bizarre Pink Flamingos by John Waters. Like other forms of cinephilia, the cult phenomenon enacts a fetish for accumulated detail and confirms the individual in an exclusive group.

The seemingly diverse objects of cult interest share the same relationship: the constitution of an aim or a domain of obsessive behaviour to ensure the possession and control of knowledge within it. There is immersion and identification, passion and mania, a proliferation of ancillary activity. Obsession and possession are twinned as the forms of pleasure are based on excessive detail and repetition: an absorption with surface rather than depth, recording information rather than analysing it. It enacts a celebratory enthrallment born of fascination rather than critical distance.

The significations of style and distance are important, it is impossible to think of cult attention within the codes of realism and films involving the spectator's submersive experience in powerful narrative. The fascination with a single film or television series ${ }^{(2)}$ (and cultists rarely spread their attentions to several films) paradoxically involves both an exaggerated respect for the film and degree of disrespect.

Ancillary production generated by The Room includes The Room Rap with the Brooklyn Doctors, the appearance of a Wiseau inspired character in an episode of The Simpsons, several dubstep remixes of favourite lines, a dozen Adobe mash ups like Hitler Calls Tommy Wiseau (joining the many parodies re-subtitling sequences from Oliver Hirschbiegel's Downfall). The digital intertexts proliferate online, there are many recordings of Greg Sestero and Tommy Wiseau at screenings with fans and even Tommy Wiseau Recites a Sonnet at one screening.

The Room combines aspiring actors like Greg Sestero as Mark and Juliette Danielle as Lisa with nonprofessionals like Carolyn Minnott who plays her gesticulating mother Claudette. Scenes are peppered with conspicuous continuity errors and non-sequiturs like the clumsy café conversation "We got a new client at the bank, we'll make a lot of money - pause - anyway, how's your sex life?" There is no logic to explain 
Lisa's changed attitude to Johnny, her mother's breast cancer, Denny's role or extraneous characters like Chris-R the drug dealer and Peter the psychologist. It is a perfectly disorganised narrative: a proliferation of plot digressions, no underlying three act structure and a refusal of redemption in the dark ending.

The awkward interposition of iconic images of recognisable locations points to subtle creative geography and the meaning of place in most film and television: CSI Miami or NYPD for instance. The Room deploys several examples of gratuitous punctuation with the cliché of incongruous San Francisco cityscapes: Golden Gate Bridge, Johnny riding a trolley car, Alcatraz and random picturesque views reminiscent of any television series set in that city. Sometimes current films try to strengthen their tenuous ties to reality and assertions of their truth status by offering reassurance about their images from exotic places: 'This film is based on real events and was made at the locations depicted', said the caption on a 2005 film about Rwanda; a protestation of authenticity which alerts one to the opposite. ${ }^{(3)}$ Getting a sense of place through the visual is crucial to the scope and texture of the narrative; it often imports a tourist dimension to contemporary cinema.

The dissolves behind gauzes, billowing curtains, red lighting, that are wrapped around the succession of long lovemaking scenes suggests familiarity with soft porn production (the bourgeois prefer the term erotic). "It's not a sex scene it's a love scene" asserts Wiseau. But the odd and non-credible configuration of the bodies and non-synchronous soundtrack of sexual groaning makes the scene strange.

The main sense of underlying authorial views is the consistent expectation that women will always betray men: "Can You Really Trust Anyone?" is the strapline on the DVD cover. Only this content of masochism and misogyny is coherent - woman as the black widow spider, drawing men's desire forward in order to destroy them. The predatory female in cinema follows the traditional genre of Death and the Maiden in painting and literature; desire leads to vulnerability and is perilous. When Mark says over the phone to Lisa "I want your body" the conjunction of desire and danger connects with his previous extraneous anecdote about a woman who was beaten and hospitalised by her cuckolded boyfriend; "What a story Mark!", Johnny responds nonchalantly.

Although it is Johnny who is self-destructive at the end of the film it is the dangerous deceiver Lisa who is to blame and not their mutual friend Mark. Johnny uses the term betrayal to describe both Lisa's sexual disloyalty and the failure to be promoted at the bank where he works, using the desperate line "Everybody betrayed me" twice. Such tropes in a film like this remind one that psychoanalytic constructions are not related to judgements of aesthetic quality. It is possible that the obsessive depiction of relationships of distrust and fear arises from a sexuality that has been pulled into mercantile relations; the interaction of bodies is now part of a pervasive pattern of commodity exchange.

The derisive laughter of sophisticated viewers is a facile dismissal which reaffirms the safety of accepted taste (the good taste of those who appreciate cinema). But a film as comprehensively maladroit as The Room raises many questions about the self-respecting films that have achieved success in contemporary cinema. The Room's sustained ineptitude only highlights the invisibility of the 'normal' codes and our reliance on them for the customary provision of pleasure. The efficient emotional involvement that powerful narrative machinery carries often conveys underlying meanings that can be seen as dubious or disputable.

From minority taste to the most popular cinema possible: Avatar was the film that the world watched at Xmas 2009 and quickly achieved the largest box office gross: $\$ 2,782,275,172 .{ }^{(4)}$ Its spectacular 3D hyperreality supposedly kept piracy at bay while the predictable tryst of the two protagonists offered a suitable poignancy for the youth market through the long looks of digitally formulated faces and wider eyes. At a superficial level the script incorporated some broad-minded aspects: there is a paraplegic as the hero, although he becomes more than able bodied in his reborn form as an avatar. Michelle Rodriguez plays an Hispanic 'diesel dyke' flying the helicopter - lesbian subculture noticed the way the character Trudy Chacon is coded (wearing a white singlet and spitting out "You're not the only one with a gun, bitch" as she flies her gunship into the attack) while the nuances of her depiction will not 'get in the way of' a mainstream audience.

There were also indications of a critique of Bush and his works: the American military industrial complex moves into action and initiates an uncalled-for attack to capture planet Pandora for a mining corporation. The operation is called 'Shock and Awe' and the wicked Colonel Miles Quaritch explains to his troops "Our only security lies in pre-emptive attack - we will fight terror with terror". It is not farfetched to assume, 


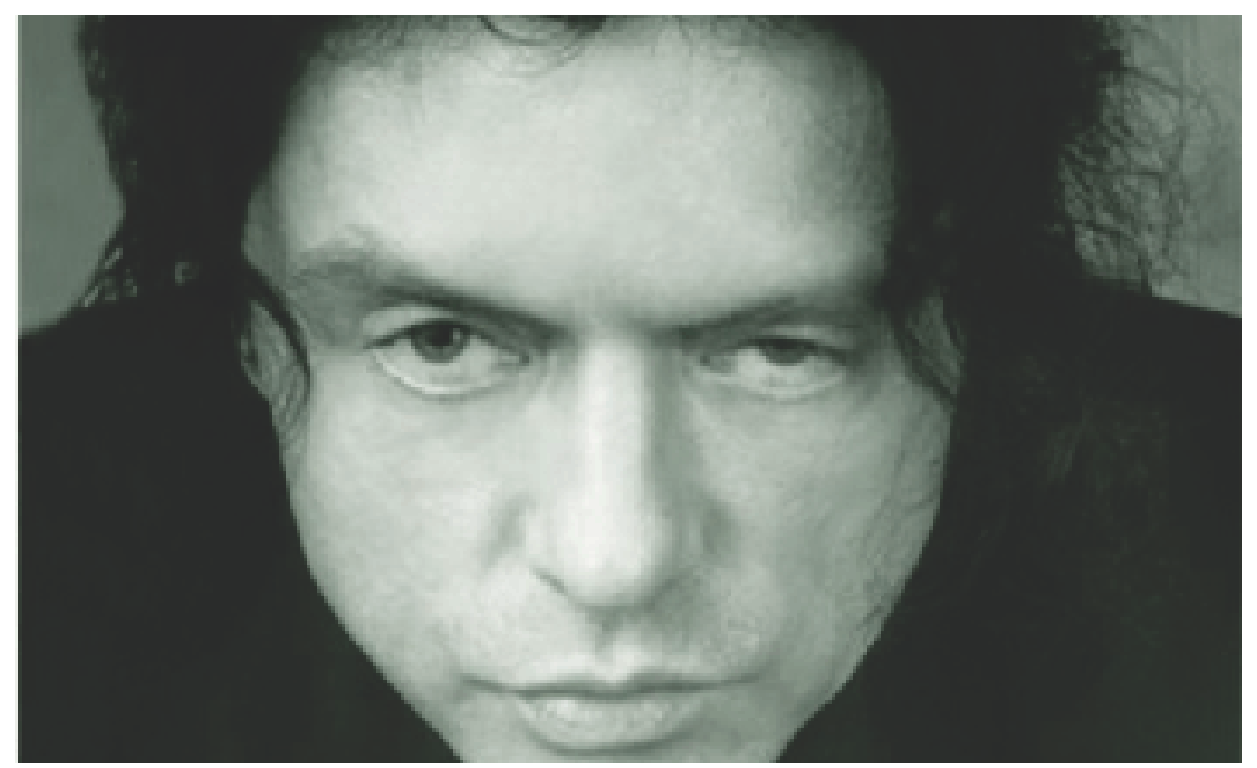

Figure 1: The Room (dir. Tommy Wiseau, 2003)

whether it is conscious or not, that the critique of American hegemony supports the film's reception and therefore its commercial success outside the US. $73 \%$ of the total gross income $(\$ 2,021,767,547)$ is taken from foreign markets and includes the myriad figures from small territories: Lebanon $\$ 1.7 \mathrm{~m}$, Mexico $\$ 44 \mathrm{~m}$ and Jamaica $\$ 476 \mathrm{~K}$ for example. James Cameron has mentioned plans for "at least two sequels" and marketing the first film's title is the beginning of establishing an international brand which will earn again in the several repetitions. Since the Second World War US cinema pursued commercial objectives through vertical integration and has achieved cultural hegemony. Narrative structures which 'work' in a diverse range of cultures are an integral part of this incursion in a world where the global audience is 100 times more likely to view a Hollywood product than a European film. ${ }^{(5)}$

The action sequences in Avatar involve a high tech attack on Pandora which threatens a gentle tribe with a combination of native ecological and spiritual features with whom we empathise. But, as Slavoj Žižek has pointed out, beneath the would-be liberal implications on the surface of Avatar lies the reactionary myth that it is (still) only the benevolent whites that can save the natives.

In contrast, The King's Speech is a successful British small-scale variant of mainstream narrative form, carried to Oscars in the USA by a powerful narrative process in English. A modest man, supported by his long-suffering wife, overcomes a physical impediment with help from friends. This constitutes a powerful and involving narrative experience, based on the full sensation of redemption and release, emotion powered by music.

When tearful eyes are wiped at the end of the film and the rational returns, the political meaning of the piece is clearer: The King's Speech is a machine which delivers us to loyalty for the royalty. The ruler's role in events should be kept in proportion as we remind ourselves that it was the squaddies depicted leaning against the army truck listening to the monarch on the radio who actually fought and sacrificed themselves in a war against Fascism in Europe. Versions of the past are always about defining the present and whatever his problems with a stammer, the King was privileged and protected. His contribution to the war effort was not one of physical jeopardy; as Godard reminds us "War is simple - you take a piece of metal and put it in a piece of flesh".

Even if they project an anachronistic political image in the early $21^{\text {st }}$ century, the global staging of a wedding last spring reminds us of the popular fascination that this particular royal dynasty continues to hold. The ensemble of the film: acting, mise-en-scène, editing, music, narrative disables critique and takes us to empathy. This is a quite arbitrary outcome, the same plot process could work for opposite ends: Guevara's 


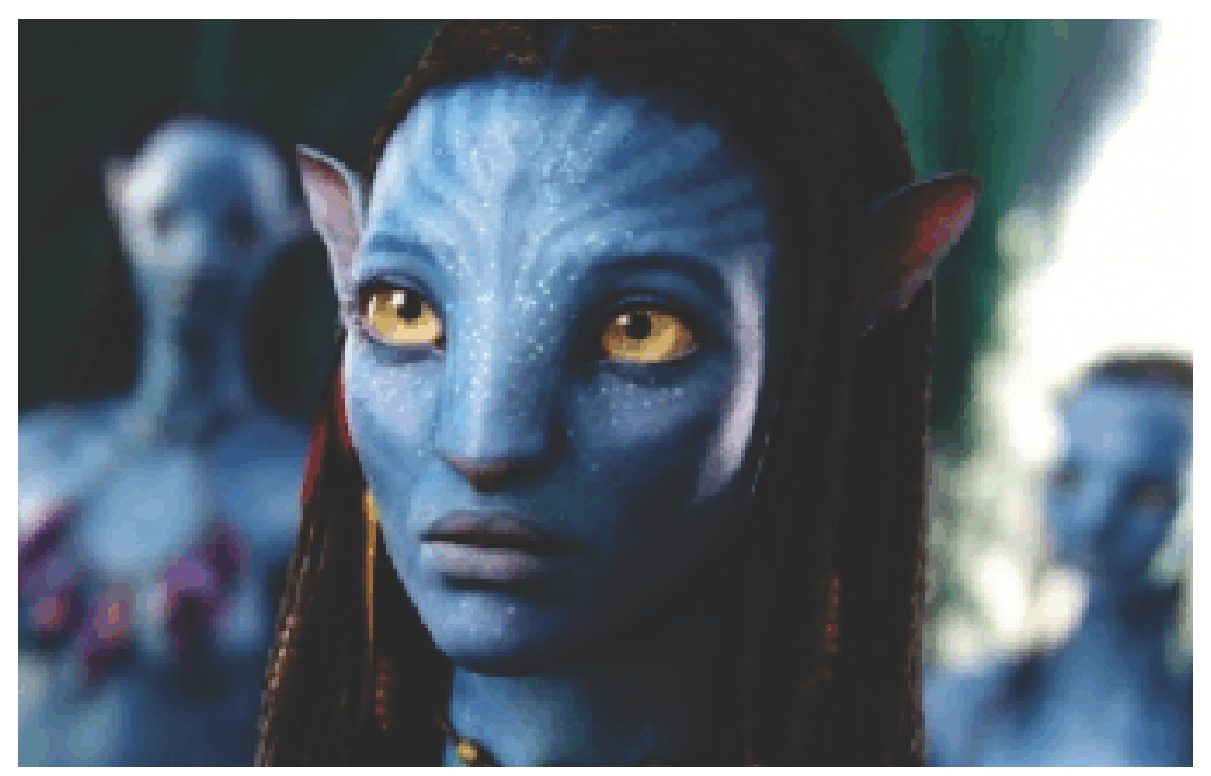

Figure 2: Avatar (dir. James Cameron, 2009)

asthma, Gramsci's hunchback, Gandhi's debilitating hookworm infection. Unsurprisingly the English of a conservative disposition love the film, seemingly it is exotic enough for Americans too. The effect is widespread, a friend who saw the film in a cinema in north Paris, a quartier with many immigrants from the Maghreb, reported that the entire cinema spontaneously burst into applause after a screening.

It is a different sort of applause that accompanies the inside jokes and cult delight that follows The Room. Every aspect of his film falls so far short of the normal and the natural that Wiseau aspires to replicate. Although audiences' laughter tends to be scornful and disparaging, not life-enhancing, the joke may be on us - The Room defamiliarises the mainstream forms that it so incompetently imitates. ${ }^{(6)}$ Of course naturalistic acting, a 'well-written' script, the elimination of non-sequitors and extraneous digressions would create the invisible narrative economy that delivers our pleasures. The Room's hapless mimesis undermines the codes that constitute the contemporary cinema and television that we normally enjoy without question and which ensure the conventional meanings that reinforce the way things are.

\section{Notes}

1. "The ultimate camp statement: it's good because it's awful." Susan Sontag, 'Notes on Camp', Against Interpretation, (New York: Picador, 1966), thesis 58.

2. Television series like Star Trek (USA, 1966-1989) or The Prisoner (UK, 1968-1969) also exemplify this.

3. Shooting Dogs (Michael Caton Jones, England, 2005).

4. http://boxofficemojo.com/movies/?id=avatar.htm (accessd 16 August 2011).

5. Scott Robert Olson, Hollywood Planet, Global Media and the Competitive Advantage of Narrative Transparency (London: Lawrence Erlbaum Associates, 1999), p. 30.

6. A similar movement occurs in other areas too - Rebecca Black's Friday is an expensive vanity video (her parents paid Ark Music Factory \$4000). It was viewed over 167 million times in its three months on YouTube and became viral because of its clumsy imitation of the clichés of music videos, an ineptitude which offers insight into the formulaic repetitions of commercialised culture, Justin Bieber's Baby for instance. Cf http://en.wikipedia.org/wiki/Rebecca_Black___Friday (accessed 11 September 2011). 


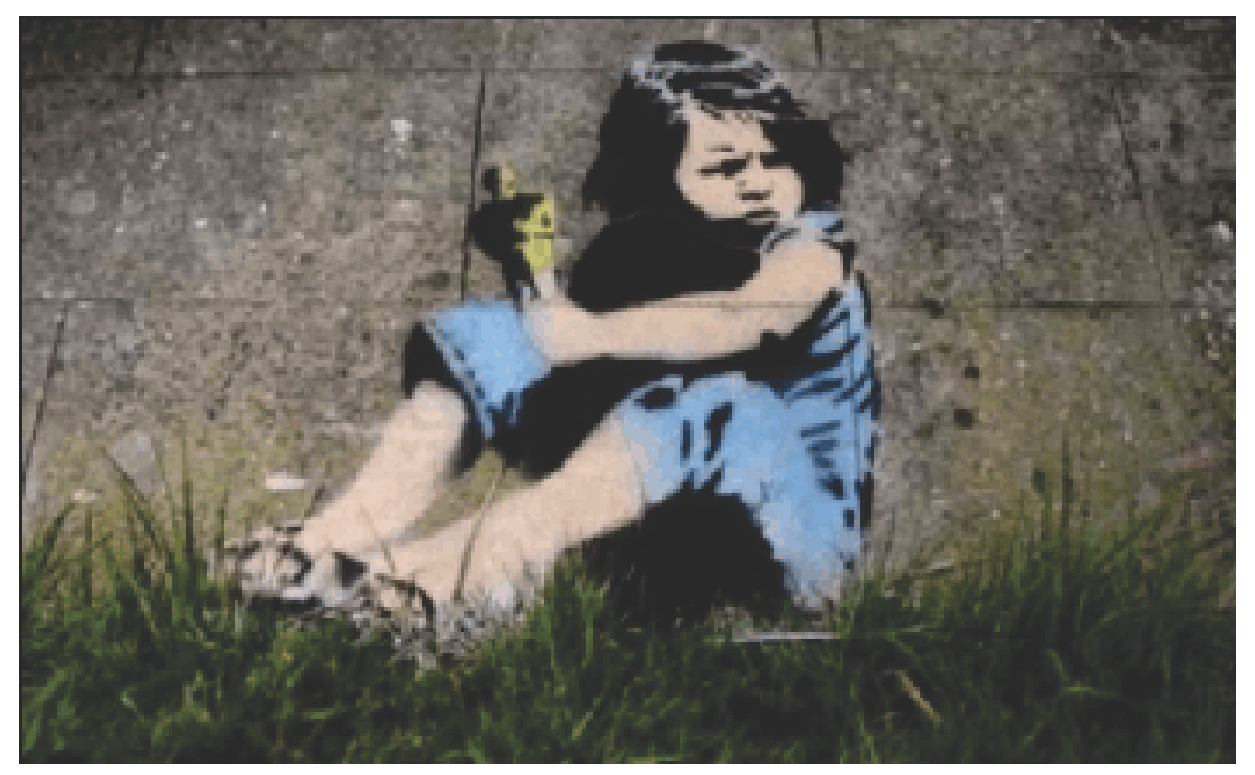

Figure 3: The King's Speech: Banksy's graffito on the side of a garage in Weston-Super-Mare, Somerset depicts Lara Egan, the 15 month old who dropped and broke her father's Oscar for The King's Speech on the night of the ceremony.

\section{References}

A shorter version of this article appeared in Film Ireland, Issue 138, Autumn 2011. Thanks to CC for the copy, AS for thoughtful contributions and SP for Paris screening.

\section{Author Information}

Rod STONEMAN is Director to Huston School of Film and Digital Media, National University of Ireland in Galway. He previously served as Chief Executive of the Irish Film Board and a deputy commissioning editor of independent film and video at Channel Four. He has made several independent programmes for television (including "Between Object and Image," "Ireland: The Silent Voices," and "Italy: The Image Business"), written for Screen, Sight and Sound, Framework, and Afterimage. 